\title{
A Review on Occupational Health and Safety Hazards as Operational Risk Can Affect Employment Commitment
}

\author{
Joseph Acquah ${ }^{1, *}$, Freda Atsunyo ${ }^{2}$, Deborah Johnson Addae ${ }^{3}$ \\ ${ }^{1}$ School of Environmental Science and Engineering, Suzhou University of Science and Technology, Suzhou, Jiangsu Province, China \\ ${ }^{2}$ School of Environmental and Sustainability, University of Saskatchewan, Saskatoon-Saskatchewan, Canada \\ ${ }^{3}$ University College of Management Studies, Kumasi, Ghana
}

Received January 14, 2021; Revised February 27, 2021; Accepted March 23, 2021

\section{Cite This Paper in the following Citation Styles}

(a): [1] Joseph Acquah, Freda Atsunyo, Deborah Johnson Addae, "A Review on Occupational Health and Safety Hazards as Operational Risk Can Affect Employment Commitment," International Journal of Social Work and Human Services Practice, Vol. 8, No. 1, pp. 11 - 16, 2021. DOI: 10.13189/ijrh.2021.080102.

(b): Joseph Acquah, Freda Atsunyo, Deborah Johnson Addae (2021). A Review on Occupational Health and Safety Hazards as Operational Risk Can Affect Employment Commitment. International Journal of Social Work and Human Services Practice, 8(1), 11 - 16. DOI: 10.13189/ijrh.2021.080102.

Copyright $\odot 2021$ by authors, all rights reserved. Authors agree that this article remains permanently open access under the terms of the Creative Commons Attribution License 4.0 International License

\begin{abstract}
Occupational health and safety hazards may have direct or indirect effects on employee participation levels in service businesses as well as other forms of industries. Adequate employment conditions and effective management of occupational health and safety (OHS) help companies attain their goals and improve job satisfaction and efficiency. Occupational, health, and safety is an inter-discipline field concerned with ensuring the protection, wellbeing, and welfare of employees or working people. Recent injuries at work have encouraged employers to place a greater focus on workplace health and safety procedures. Occupational safety and health risks are issues associated with safeguarding the life, health, and wellbeing of individuals employed or living. Occupational safety and health services have as their goals for the development of a safe and secure work atmosphere. Job-related tension, disputes, work capacity problems, ill health, and other hazards OHS workplace conditions can hinder employee well-being and productivity. Employers are responsible for handling risks and addressing challenges within the work environment according to OHS regulations. This study was to describe occupational health and safety hazards as operational risk-related issues affecting employment commitment and the support they require in these situations.
\end{abstract}

Keywords Organization Health and Safety (OHS), Wellbeing, Employment Commitment, Safety Performance, Management

\section{Introduction}

Occupational health and safety (OHS) is commonly characterized as the science of predicting, recognizing, assessing, and handling workplace-related hazards which could affect employees ' health and well-being, taking into account the possible impacts on the local residents as well as the environment in general [1]. Occupational health and safety is the human well-being concern that drives the development of the industrialization and service sectors this day, contributing to a growing occupational health crisis, despite substantial progress in improving OSH over the past decade, An estimated three hundred and seventeen (317) million non-fatal work-related injuries and 321,000 work related deaths occur worldwide every year, that is one hundred and fifty-one (151) workers suffer a work related accident every fifteen (15) seconds (ILO 2013). An approximate 6.9 million workplace accidents occurred during 2006 in the European Union (EU) and 8.5 million during 2007 in the U.S [2, 3].

Occupational safety and health hazards are also seen as a guiding force for seeking ways to eliminate harmful effects for workers from the industrial sectors. The quality, health, education, and safety standards have been much more stringent in many countries in recent years than were previously seen in the case. [4] argues that numerous 
international and national safety principles direct organizations in designing their security management systems (SMS) concerning varying business needs and specifications. Even though people work and spend much of their work time in the workplace, little funding and energy are provided to occupational health and safety [5].

In today's world, several organizations are seeking to boost the OHS of their employees. Studies indicate that health and safety are generally ensured by compliance with legal legislation, the implementation of a governance structure and the creation of a healthy and secure workplace environment [6]. Working to improve the safety culture within an organization, however, is not only done with effective internal pressure, but also with a change in opinion and a true dedication of all employees to OHS issues. This commitment should start with all representatives of the company from the higher leadership [7]. Therefore, having and enforcing an OHS Management Framework is a strong opportunity for organizations planning to behave according to the laws on workplace safety and a healthy safety culture.

Although most of the potential hazards introduced into the business sector are because the devices have become bigger, more powerful, and much more complex in service. The materials and production activities had become more complicated than infused possible health hazards in the workplace. Employees have had to cope with job stress because of mechanization and the need for improved efficiency that has improved their well-being [8-10]. The aim of implementing new technology and flexible manufacturing methods is to shorten process times and optimize productive working time, thereby increasing work speed and intensity. This creates frustration and stress levels which lead to psychosocial and ergonomic problems [11].

Naturally, human beings want to work in a comfortable and secure world free of all risks to their physical and mental lives, which are more easily achieved by taking the required steps in protection. Employees who are satisfied with their jobs perform their tasks better and show greater commitment to their role and organization [12]. Organizations should also pay close attention to gaining their employees' interests when making an investment in an OHS management system intended to be used to prevent and reduce occupational injuries and increase efficiency in safety [13].

In this respect, this study analyzed employment commitment to OHS, employee satisfaction, and the safety performance and effect of OHS as operational risk on employee commitment.

\section{Employment Commitment to OHS}

Employment's commitment to workplace safety reflects the degree to which an organization's top management prioritizes workplace protection during the decision-making process and how much money is provided for it. Commitment to work has been a concern of scientists for many years. Similarly, for its results such as increased strategy, higher job satisfaction, lower absenteeism, and more worker employment within the company, practitioners have shown a strong interest in workplace engagement [14]. Commitment to work is a priority for contemporary organizations. The employment commitment of high-performance staff leads to competitive advantage particularly in times of crisis and business interruptions. Organizations that struggle to build dedication to jobs will weaken the sources of potential competition [15]. Also, in the study on strategic human resource management, different research analyzed the high commitment management model and high-performance work processes, or the employee engagement (OCE) model.

Controlling hazardous situations, sufficient physical working environments, rewarding and appreciation, cultivating friendship and partner, and jointly providing a productive and professional working atmosphere for workers in jobs are obvious. Organizations can build work environments to enhance the degree of organizational engagement and motivation and to increase efficiency [16].Tools used to monitor the work environment and improve efficiency include noise reduction, waste control, and hazard management, enhancing communication, creating a more humane environment, health for the worker in the workplace, incentives, reviews, modeling the ideal work environment, improving the quality of professional life and creating appropriate physical employment conditions [17].

Employment commitment is divided into three elements, respectively, of effective, ongoing, and normative participation. The effective engagement model of Meyer and Allen reflects the degree to which an individual identifies with, participates in, and enjoys the participation of an organization. Staff with strong emotional commitment wants to work because they want to remain inside the organization. Continued commitment to the integrity of a worker as to what it would cost to leave the company for that job. Individuals whose organizational loyalty is marked by consistency prefer to remain within the organization regardless of their needs. Normative participation requires a sense of worker's moral duty to continue to work for the organization. People have a strong organizational commitment not because they like it, but because they deem it virtuous [18].

Employment commitment of the staff is a major indicator of their effects on the company's success. The primary explanation for this is the fact that organizationally committed employees to prefer to remain in the same organization for prolonged periods. Moreover, such employees are more interested in performing their jobs. Organizational commitment is also correlated with how employees accomplish organizational and corporate 
identity goals, and organizational loyalty [19].

\section{Safety Performances}

Safety performance can be described as the evaluation of tasks done out to protect workers from work - related accidents and occupational diseases [20]. An organization's performance assessment framework requires two different monitoring data; proactive (positive) and reactive data (negative). For measuring and reporting, proactive data should be used. When safety performance is insufficient, reactive data should be used [21]. Negative performance indicators focused on accident ratios are useful for handling accidents that lead to employee injuries, but not for managing large risks [21].

Employment commitment will potentially impact the entire organization's efficiency. Commitment is also a quality that companies greatly seek, and that inspires the workers. Although the studies do not prescribe coherent results as to whether success is a consequence of commitment to employment, it would not be incorrect to say that commitment is a deciding factor of high performance since positive working attitudes will produce positive job outputs [22,23].

\section{Effect of OHS as Operational Risk on Employment Commitment}

OHS challenges are increasingly related to the organizations' job performance and productivity [24].For example, when an organization has a high number of injuries, it is unlikely to achieve maximally efficient efficiency and quality [25]. Various issues associated with factors at the individual, group, and organizational levels adversely affect an organization's performance. The human, social, and economics costs of accidents at work, injuries, illness, and significant and industrial hazards including workers' compensation claims, medical expenses, and loss of productivity, have long been caused by the individual worker to the domestic and international for concern at all stages.

According to [26], workers with a high effective engagement display emotional attachment/identification with and participation in the organization, and those workers are less likely to participate in withdrawal behaviors such as absenteeism, poor performance, and turnover $[27,28]$. Such examples include eye irritation, respiratory illnesses, skin infections, minor injuries caused by walking on broken bottles or sharp objects in the refuse, chronic problems from bending down much of the time, and headaches caused by sun work. Besides the lack of safety equipment, toxic odors at waste disposal and flea prevalence make employment conditions even more unhygienic. From a study performed in Thailand, it can be noticed that low back pain and sprains, chronic colds, and skin rashes involve workers suffering daily work physical health issues. Such problems include headaches, fatigue, and shortness of breath. Several other employees do not use PPE and thus endanger their health, employees with low levels of education have much more injuries with jobs [29].

All places of work present hazards and threats. Hazards can lead to injuries, damage, and even fatal accidents. OHS are also a very necessary aspect of every workplace since in most situations' workers' lives rely on it. Below are OHS hazards as the operational risk that employees are exposed to on employment commitment:

Chemical hazards liquid, solid, or gas may be a chemical threat. It may be a single material or a combination of substances, consisting of one element. The health of an individual who is exposed to it may be harmed. Cleaning solutions and solvents, skin allergic reactions, vapors and fumes, carcinogens, respiratory sensitizers, carbon monoxide and other gases are chemical hazards.

Biological hazards Natural substances that present a danger to the health of humans and other living organisms are biological hazards. Experts in healthcare are at more risk for this form of risk. Examples of biological hazards include: bacteria, Viruses, biological toxins, blood or other body fluids, spores, fungi, animal treatment, insect bites, pathogenic micro-organisms and bioactive substances.

Physical hazards Physical hazards are environmental variables or situations that can affect your health. This has been the most common kind of threat in the workplace. Exposure to loud sounds, slips, slides, falls, vibrations, body stress, enclosed spaces, energy, heat and heights are examples of physical hazards.

Ergonomic hazards Physical factors that can cause musculoskeletal injuries are ergonomic hazards. This includes improperly changed computers and seats, frequent lifting, bad posture, awkward movements, especially if they are frequent, to use too much force, especially if it is performed on a daily basis, and vibration.

Psychosocial hazards Psychosocial threats are components of work that may cause psychological or physical damage. These include tension, tiredness, abuse, intimidation, hostility, harassment and burnout, which can be detrimental to employees' wellbeing and compromise their well-being.

Occupational Health and Safety can be seen to have important influences on employment commitment. OHS at the workplace is often considered to influence the attitudes of workers about their commitment to the organization. Employment commitment can affect the overall performance of employees and the productivity of the firm and is like an organizational glue that connects employees and generates a sense of accomplishment among employees as part of that organization. 
According to [30], employees who have been well and remain safe in the workplace are the ones who dedicate their expertise to work and take full advantage of their abilities. When companies struggle to fix unsafe working conditions in the OHS, workers are more likely to determine that the risks of remaining with the company outweigh the risks of leaving. This suggests that the lower the employment commitment and vis-verse, the higher the OHS problems.

The employee commitment relationship is related to job satisfaction behaviors as well as employee participation, development and growth, work-life balance, acknowledgment, and OHS [31]. The outcomes of employees would be employment commitment, emotional fatigue, mental well-being, and plans of labor turnover when companies have good OHS practices in their workplace. A study conducted in China by [32], the findings of a strong relationship between affective commitment and physical well-being of an employee, indicates that organizational management must be concerned about the workplace's OHS to improve employee commitment to have dedicated employees.

This study also examined the correlation between occupational health and safety and commitment to work, which illustrates the direct influence of OHS practices on organizational commitment. As workers thus have a favorable view of their job by the OHS organization, their emotional connection and connection with the company is strengthened. Employees with a high-level affective commitment to work show emotional involvement with and engagement in the company and such workers are less likely to indulge in withdrawal activities such as absenteeism, poor performance, and turnover of labor. Good occupational health and safety policies at the workplace have a direct impact on the understanding of workers' normative commitment. According to [33], for organizations to cultivate the loyalty of workers, especially those employed in the extremely dangerous workplace, their health and safety has to be a senior management priority or concern to improve employee commitment. Employee normative commitment can be established when a company is costly to provide jobs, like investing in workplace occupational health and safety education and training [18]. This type of commitment can be used to predict employees' turnovers. However, the more employees feel safe at the workplace, the more they will feel loyal and obligated to their organization which terms to reduce labor turnover.

Healthy occupational health and safety practices also influence employment continuance commitment. Employees' views of the company's OHS impact their stay in the organization and make a positive contribution to the organization. Employees thus consider OHS to be necessary and acceptable in the organization, and more possibly they have an enduring partnership with the organization believing that the organization guarantees their health, protection, and welfare.

When organizations struggle to resolve poor working conditions such as infectious diseases, transport incidents, violence in the workplace, falling and slipping, toxic events, notably gas and chemical exposure, objects being struck, electric shock or explosion, repetitive movements, and ergonomic illnesses, and hearing problems, there will be a decrease in the continuing commitment of employees to the organization. For example, employed in particularly risky organizations like mines, employers must have healthy OHS programs that protect the health, safety, and wellbeing of employers.

The effect of OHS as operational risk on employment commitment can outweigh the rewards, as workers or employees will terminate or abandon their commitment. Employees may then assess their association with their organizations and make an educated decision about whether their organizations should have a personal, consistent or acceptable relationship to preserve their health, safety, and wellbeing in the workplace to be committed.

Reciprocal action is "modeled as a behavioral response to an action that is perceived as either kind or unkind. The more an action is considered as kind or unkind, the more it will be rewarded or punish, respectively" [34]. The commitment of employees, therefore, decreases when employees believe that their employer does not care about their health, safety, and welfare by displaying job habits such as low efficiency, absenteeism, intention to leave the company, and weak commitment.

It is claimed that there is an acceptable match between the type of OHS activities and the type of commitment of employees that would be advantageous to an organization's success if correctly balanced. Therefore, it is evident that OHS practices have an impact on the commitment of employees.

\section{Conclusions}

In conclusion, the paper identified occupational health and safety risks as problems related to operational risk affecting the commitment to jobs and the support they need in these circumstances. It also addressed the commitment of employment to OHS, safety efficiency and the effects of OHS as an operational risk on the commitment to employment. Management must consider the fact employees who feel confident and secure in carrying out their duties, cultivate emotional commitment and have a sense of responsibility to their organization and are often undoubtedly committed to the employer.

Employees are not only loyal or committed to the organization; instead, by introducing fair and sound governance initiatives, they want management to first think about their health and safety needs. This paper recommends the need for organizations to invest in 
maintaining the health and safety of employees in organizations as $\mathrm{OHS}$ is an integral part of employer management. Organizations must also invest in risk assessment regularly to find out about the risks and hazards in their work environment and put in place effective and efficient controls and measures to reduce or eliminate these risks and hazards for the safety of employees. OHS require pursuant to laws and regulations, it is the responsibility of employers to do so. Organizational management, for example, must demonstrate good leadership and commitment to $\mathrm{OHS}$ operations in the workplace and make suitable plans for the development of an OHS management structure. Management of organizational structures must include the core main elements of strategy, structure, preparation and execution, assessment and action for change. Organizations' ability to increase the degree of employee motivation and commitment, and enhance effectiveness may depend upon the nature of the working environments.

\section{Measures to Improve Occupational Safety}

Safety problems in the workplace can be present in any sector, but they are especially prevalent in industries such as transport, manufacturing and construction. However, to present a risk, the work does not have to be of a physical nature. They all have their own range of dangers for workplaces, classrooms, and retail outlets. The promotion and follow-through of occupational safety programs and safety awareness is critical. These measures to improve occupational safety include:

1. Establish a culture of safety in the workplace

2. Enable quick access to information on safety

3. Reward defensive conduct

4. Act with doctors and occupational therapists

5. From the beginning, use safety directives

6. Keep Open Contact Networks

7. Keep regularly scheduled meetings on occupational safety

\section{Declaration}

The authors have no conflicts of interest to declare that are relevant to the content of this article.

\section{REFERENCES}

[1] Kumar, M. S., Goud, B. R. \& Joseph, B. A study of occupational health and safety measures in the Laundry Department of a private tertiary care teaching hospital, Bengaluru. Indian J. Occup. Environ. Med. 18, 13 (2014). https://www.ijoem.com/text.asp?2014/18/1/13/134951
(Accessed July 14, 2020).

[2] Chau, N. et al. Roles of age, length of service and job in work-related injury: a prospective study of 446120 person-years in railway workers. Occup. Environ. Med. 67, 147-153 (2010).

[3] Leigh, J. P. \& Marcin, J. P. Workers' compensation benefits and shifting costs for occupational injury and illness. $J$. Occup. Environ. Med. 54, 445-450 (2012). DOI: 10.1097/JOM.0b013e3182451e54

[4] Ahonen, G. Good Practice in Occupational Health Services: A Contribution to Workplace Health. WHO Regional Office for Europe. World Heal. Organ. Eur. (2002). https://apps.w ho.int/iris/handle/10665/107448 (Accessed August 22, 2020

[5] Michaels, D., Barrera, C. \& Gacharna, M. G. Economic development and occupational health in Latin America: new directions for public health in less developed countries. Am. J. Public Health 75, 536-542 (1985). https://doi.org/10.210 5/AJPH.75.5.536

[6] Vandyck, E., Fianu, D., Papoe, M. \& Oppong, S. Safety management systems, ergonomic features and accident causation among garment workers. Les Actes la troisièmeConférenceinternationale sur Les Appl. l'ergonomiedans les pays envoie développement 109-114 (2015). http://www.prevention-ergonomics.com/ar/Paper\%2015\%2 0Efua\%20Vandyck\%20et\%20al\%20\%20Ergo\%202015.pdf (Accessed 10 July 2020)

[7] Beatriz, F., Jose, M. P. \& Camilo, J. Relation between occupation safety management and firm performance. Saf. Sci. 47, 980-991 (2009). https://doi.org/10.1016/j.ssci.2008 .10 .022

[8] Kaminski, M. Unintended consequences: organizational practices and their impact on workplace safety and productivity. J. Occup. Health Psychol. 6, 127 (2001). https://doi.org/10.1037/1076-8998.6.2.127

[9] Shannon, H. S., Robson, L. S. \& Sale, J. E. M. Creating safer and healthier workplaces: role of organizational factors and job characteristics. Am. J. Ind. Med. 40, 319-334 (2001). https://doi.org/10.1002/ajim.1106

[10] Zacharatos, A., Barling, J. \& Iverson, R. D High-performance work systems and occupational safety. $J$. Appl. Psychol. 90, 77 (2005). https://doi.org/10.1037/00219010.90.1.77

[11] Harrisson, D. \& Legendre, C. Technological innovations, organizational change and workplace accident prevention. Saf. Sci. 41, 319-338 (2003). https://doi.org/10.1016/S0925 $-7535(02) 00041-3$

[12] Rajeswari, P. \& Rajakrishnan, V. S. An analysis of job dimensions on organizational commitment with special reference to sales representatives at Nagapattinam district. Int. J. Advenced Sci. Res. Dev. 2, 10-20 (2015). DOI: $10.4103 / 0019-5278.134951$

[13] Wachter, J. K. \& Yorio, P. L. A system of safety management practices and worker engagement for reducing and preventing accidents: An empirical and theoretical investigation. Accid. Anal. Prev. 68, 117-130 (2014). https://doi.org/10.1016/j.aap.2013.07.029

[14] Morrow, P. C. Managing organizational commitment: 
Insights from longitudinal research. J. Vocat. Behav. 79, 1835 (2011). http://dx.doi.org/10.1016/j.jvb.2010.12.008

[15] Neininger, A., Lehmann-Willenbrock, N., Kauffeld, S. \& Henschel, A. Effects of team and organizational commitment-A longitudinal study. J. Vocat. Behav. 76, 567-579 (2010). http://dx.doi.org/10.1016/j.jvb.2010.01.00 9

[16] Danish, R. Q., Ramzan, S. \& Ahmad, F. Effect of perceived organizational support and work environment on organizational commitment; mediating role of self-monitoring. Adv. Econ. Bus. 1, 312-317 (2013). https://doi.org/10.13189/AEB.2013.010402

[17] Taiwo, A. S. The influence of work environment on workers productivity: A case of selected oil and gas industry in Lagos, Nigeria. African J. Bus. Manag. 4, 299-307 (2010). https://academicjournals.org/article/article1380705375_Tai wo.pdf (Accessed 28 July 2020)

[18] Meyer, J. P. \& Allen, N. J. A three-component conceptualization of organizational commitment. Hum. Resour. Manag. Rev. 1, 61-89 (1991). http://dx.doi.org/10. 1016/1053-4822(91)90011-Z

[19] Yeh, Y.-P. Exploring the impacts of employee advocacy on job satisfaction and organizational commitment: Case of Taiwanese airlines. J. Air Transp. Manag. 36, 94-100 (2014). http://dx.doi.org/10.1016/j.jairtraman.2014.01.002

[20] Safety, A. \& Council, C. Guidance on the Use of Positive Performance Indicators to Improve Workplace Health and Safety. (2005). https://www.yumpu.com/en/document/view /24696912/guidance-on-the-use-of-positive-performance-in dicators-safe-work-( Accessed 16 August 2020)

[21] Bayram, M. The Management Commitment to OHS, Employee Satisfaction and Safety Performance: An Empirical Study. Int. J. Latest Eng. Manag. Res. 3, 63-71 (2018).

http://www.ijlemr.com/papers/volume3-issue7/9-IJLEMR33258.pdf. (Accessed 29 August 2020)

[22] Camilleri, E. Some antecedents of organizational commitment: Results from an information systems public sector organization. Bank Valletta Rev. 25, 1-29 (2002). https://www.semanticscholar.org/paper/Some-Antecedentsof-Organisational-Commitment $\% 3 \mathrm{~A}$-from-Camilleri/1671a 46871bc725a66cb6c69b6df93001153e9df. (Accessed 20 August 2020)

[23] Sığrı, Ü. An analysis of organizational commitment using meyer and allen's typology: a comparative study on public and private sector employees. Anotolia Univ. J. Soc. Sci. 7, 261-278 (2007). https://ideas.repec.org/a/and/journl/v7y20 07i2p261-278.html Accessed 24 August 2020

[24] Boyd, C. Human resource management and occupational health and safety. (Routledge, 2004). https://doi.org/10.432 4/9780203428061

[25] Carder, B. \& Ragan, P. W. A survey-based system for safety measurement and improvement. J. Safety Res. 34, 157-165 (2003). https://doi.org/10.1016/S0022-4375(03)00007-0

[26] Zeidan, S. Workers' affective commitment and their willingness to perform discretionary work behaviour: the impact of commitment-oriented human resources management practices. J. Law Gov. 1, (2006). https://doi.org/10.15209/jbsge.v1i1.77

[27] A'yuninnisa, R. N. \& Saptoto, R. The effects of pay satisfaction and affective commitment on turnover intention. Int. J. Res. Stud. Psychol. 4, 57-70 (2015). https://doi.org/1 0.5861/ijrsp.2015.1055

[28] Dixit, V. \& Bhati, M. A study about employee commitment and its impact on sustained productivity in Indian auto-component industry. Eur. J. Bus. Soc. Sci. 1, 34-51 (2012).

https://www.academia.edu/6265300/EJBSS_12_1147_A_St udy_about_Employee_Commitment. (Accessed August 20, 2020)

[29] Khalil, A. \& Milhem, M. Investigation of Occupational Health and Safety Hazard Among Domestic Waste Collectors in Bethlehem and Herbron Districts. (2004). https://staff-old.najah.edu/sites/default/files/investigation_o f_occupational_health_and_safety_hazards_among_domest ic_waste_collectors_in_bethlehem_and_hebron_districts.pd f( Accessed July 30, 2020)

[30] Cole, G. A. Personnel and human resource management. (Cengage Learning EMEA, 2002). https://www.scirp.org/(S (vtj3fa45qm1 ean45vvffcz55))/reference/ReferencesPapers. aspx?ReferenceID=1696218. (Accessed August 19, 2020)

[31] Grawitch, M. J., Trares, S. \& Kohler, J. M. Healthy workplace practices and employee outcomes. Int. J. Stress Manag. 14, 275 (2007). https://doi.org/10.1037/1072-5245. 14.3.275

[32] Siu, O. Occupational stressors and well - being among Chinese employees: The role of organisational commitment. Appl. Psychol. 51, 527-544 (2002). https://doi.org/10.1111/ 1464-0597.t01-1-00106

[33] Cooper, D. Measurement of safety climate: a component analysis. Institute of Safety Health (IOSH) meeting on $1 \mathrm{Feb}$ 1995 [Internet]. (1995). http://www.bAsafe.net/articles/bsm s1.pdf. (Accessed August 21, 2020)

[34] Falk, A. \& Knell, M. Choosing the Joneses: On the endogeneity of reference groups. Inst. Empir. Res. Univ. Zurich, Work. Pap. (2000). http://www.econ.uzh.ch/static/w p_iew/iewwp053.pdf (Accessed June 10, 2020) 